\title{
PENERAPAN MODEL PEMBELAJARAN KOOPERATIF TIPE SNOWBALL TROWING DALAM MENINGKATKAN HASIL BELAJAR GEOGRAFI PADA MATERI SEBARAN FLORA DAN FAUNA DI INDONESIA KELAS XI IPS-2 SMA NEGERI 5 BINJAI TAHUN PELAJARAN 2014/2015
}

\author{
Suryati \\ Guru SMA Negeri 5 Binjai
}

\begin{abstract}
ABSTRAK
Tujuan yang akan dicapai dalam Penelitian Tindakan Kelas ini adalah: "Untuk mengetahui pengaruh penerapan model pembelajaran kooperatif tipe Snowball Trowing dalam meningkatkan hasil belajar geografi pada materi sebaran flora dan fauna di Indonesia kelas XI IPS-2 SMA Negeri 5 Binjai Semeter I Tahun Pelajaran 2014/2015. Jenis penelitian ini adalah Penelitian Tindakan Kelas (PTK). Prosedur tindakan kelas (PTK) merupakan penelitian dengan menggunakan proses pengkajian melalui system berdaur (siklus) dari berbagai kegiatan pembelajaran. Siklus yang dimaksud melalui tahap perencanaan, tindakan, observasi, dan refleksi. Untuk penelitian ini direncanakan sampai 2 siklus. Berdasarkan hasil diskusi dengan pengawas maka pembelajaran yang dilaksanakan sudah menunjukkan kemajuan. Hal ini ditunjukkan dengan adanya keberhasilan siswa yang dapat menguasai pelajaran Geografi pada materi persebaran flora fauna di indonesia dimana hasil yang diperoleh adalah $87,5 \%$ tuntas dalam pembelajaran lebih dari $75 \%$ yaitu $87,5 \%$ pada siklus II. Disamping itu juga terdapat kemajuan dalam hal prestasi belajar dimana nilai siswa dari pra siklus ke siklus I, dan dari siklus ke Siklus II.
\end{abstract}

Kata Kunci: model pembelajaran kooperatif tipe snowball trowing, hasil belajar geografi, sebaran flora dan fauna

\section{PENDAHULUAN}

Pendidikan memegang peranan penting untuk menjamin kelangsungan hidup suatu bangsa dan negara. Oleh karena itu pendidikan berperan dalam menghasilkan sumber daya manusia. Pendidikan yang berkualitas tinggi akan membawa kemajuan suatu negara. Sebaliknya, terhambat atau merosotnya pendidikan akan menghambat pembangunan Negara yang bersangkutan.Saat ini sering terdengar sorotan dan kritikan tentang lemahnya proses pembelajaran yang di hadapi dunia pendidikan. Dalam proses pembelajaran anak kurang didorong untuk mengembangkan kemampuan berpikir, dan proses pembelajaran di dalam kelas di arahkan kepada kemampuan anak untuk menghadapi informasi. Pembekalan terhadap tenaga pendidik sangat diperlukan untuk menghindari mutu pendidikan yang kurang baik (Sanjaya, 2008). Untuk menghasilkan anak yang cerdas, sekolah perlu membekali meraka dengan penalaran, keterampilan, dan sikap ilmiah yang memadai (Ikhsan, 2005). Cara belajar mengajar yang kurang baik, bahan bacaan yang kurang mendukung,bahan 
pelajaran yang tidak sesuai dengan kemampuan akan menghambat peran sekolah dalam upaya pendidikan yang lebih baik. Pada kenyataannya kualitas pendidikan di Indonesia masih rendah dan menjadi masalah yang sangat besar di indonesi. Dalam dunia pendidikan Indonesia hanya menempati urutan 102 dari 107 negara di dunia dan urutan 41 dari 47 negara Asia, Engkoswar, (2007). Ada banyak faktor penyebab yang dapat mempengaruhi rendahnya hasil belajar siswa. Para ahli pendidikan telah banyak mengemukakan pendapatnya tentang hal ini, sebagai mana yang telah di kemukakan oleh Hutagaol (1992) bahwa : faktor-faktor penyebab rendahnya hasil belajar siswa antara lain: (1) system pengajaran yang kurang efektif, kurang efisien dan kurang membangkitkan gairah belajar siswa, (2) kualitas rancangan pengajaran siswa yang kurang menarik minat belajar siswa.

Fenomena ini menujukkan bahwa masih perlu dilakukan berbagai usaha untuk meningkatkan mutu pendidikan. Salah satu usaha untuk meningkatkan mutu pendidikan dapat di tempuh melalui penggunaan strategi belajar yang mampu mengembangkan cara belajar siswa aktif. Dengan demikian guru harus menguasai berbagai bentuk metode mengajar dan menggunakan metode yang sessuai untuk setiap metode yang diajarkannya. Nawawi (1985) menyatakan bahwa "metode mengajar adalah kesatuan langkah kerja yang di kembangkan oleh guru berdasarkan pertimbangan nasional tertentu, masing-masing jenisnya bercorak khas dan kesemuanya berguna untuk mencapai tujuan pengajaran tertentu". Oleh karena itu meningkatnya hasil pembelajaran antara lain diperoleh dari memilih metode yang baik atau tepat untuk menciptakan proses belajar mengajar yang baik. Dalam memilih dan merangkaiberbagai metode mengajar di pengaruhi oleh beberapa faktor antara lain adalah tujuan pengajaran ,besarnya kelas ,kemampuan siswa, fasilitas yang tersedia, kemampuan guru dan waktu yang tersedia. Kemampuan penguasaan terhadap berbagai metode pembelajaran merupakan salah satu diantara 10 kompetensi (kemampuan) dasar guru yang mutlak diperlukan oleh guru agar ia berhasil dalam melaksanakan tugasnya. Jadi,seorang guru harus benar-benar memiliki kompetensi dalam memilih metode yang tepat dan efektif dalam mengajarkan materi pelajaran kepada siswa.

pendidikan merupakan salah satu bidang yang sangat penting dan memerlukan perhatian khusus dari semua lapisan masyarakat, bukan hanya pemerintah yang bertanggung jawab atas keberhasilan dan kemajuan pendidikan di Indonesia, akan tetapi semua pihak baik guru, orang tua, maupun siswa sendiri ikut bertanggung jawab. Contoh PTK IPS geografi SMA Sekolah merupakan suatu institusi atau lembaga pendidikan yang mampu berperan dalam proses edukasi (proses pendidikan yang menekankan pada kegiatan mendidik dan 
mengajar), proses sosialisasi (proses bermasyarakat khususnya bagi anak didik), dan proses transformasi (proses perubahan tingkah laku ke arah yang lebih baik).

Proses pembelajaran melalui interaksi guru-siswa, siswa-siswa, dan siswa 7 guru, secara tidak langsung menyangkut berbagai komponen lain yang saling terkait menjadi suatu sistem yang utuh. Pendidikan dapat mengalami perubahan ke arah yang lebih baik bahkan sempurna sehingga sangat diharapkan adanya pembaharuan-pembaharuan. Salah satu upaya pembaharuan dalam bidang pendidikan adalah pembaharuan metode atau meningkatkan relevansi metode mengajar. Metode mengajar dikatakan relevan jika mampu mengantarkan siswa dalam mencapai tujuan pendidikan.Seorang guru yang baik harus mampu menyusun suatu strategi pembelajaran yang mampu membawa siswa berperan secara aktif dalam belajar dikarenakan kesadaran dan ketertarikan siswa yang cukup tinggi, bukan semata $\neg$ mata untuk memenuhi kewajiban. Guru dituntut dapat menyajikan kegiatan belajar mengajar yang mampu membangkitkan motivasi belajar siswa. Motivasi belajar merupakan motor penggerak yang menjadikan siswa secara aktif melibatkan diri untuk belajar. Usaha guru untuk membangkitkan motivasi belajar pada siswa diarahkan pada unsur internal (siswa) dan unsur eksternal (di luar siswa). Contoh dari unsur eksternal tersebut adalah suasana kelas yang efektif untuk belajar. Upaya Peningkatan Hasil Belajar Georafi Pada Materi Sebaran Flora Dan Fauna Di Indonesia Dengan Metode Pembelajaran Kooperatif Tipe Snowball Trowing Kelas XI IPS-2 SMA Negeri 5 BinjaiTahun Pelajaran 2014/2015 untuk mewujudkan hal ini, sangat diperlukan peran guru secara aktif, sebab guru sebagai pengelola proses pembelajaran bertindak selaku fasilitator hendaknya berusaha menciptakan kondisi pembelajaran yang kondusif, mengembangkan bahan pengajaran dan meningkatkan kemampuan siswa untuk menyimak dan menguasai tujuan pendidikan yang harus mereka capai, oleh karena itu guru dituntut mampu mengelola proses pembelajaran yang dapat memberikan rangsangan kepada siswa sebagai subyek utama belajar. Diharapkan dalam proses belajar mengajar dapat terjadi aktivitas dari siswa yaitu siswa mau dan mampu memecahkan masalah, berfikir, menjawab pertanyaan, diskusi, dan memperhatikan pada semua kegiatan pembelajatan di kelas. Selain itu, diharapkan pula siswa mampu berinteraksi secara positif antara siswa yang satu dengan siswa yang lain maupun antara siswa dengan guru apabila ada kesulitan-kesulitan yang dihadapi dalam belajar, sehingga masalah yang dihadapi mudah diselesaikan secara bersama-sama antar mereka. Dalam memilih metode mengajar harus disesuaikan dengan tujuan pengajaran, materi pengajaran dan bentuk pengajaran (kelompok atau individu). 
Metode mengajar ada beberapa macam misalnya: ceramah, diskusi, demonstrasi, inquiri, kooperatif dan masih banyak lagi. Selama beberapa kurun waktu, pembelajaran yang dianut oleh beberapa guru didasarkan atas asumsi bahwa pengetahuan dapat dipindahkan secara utuh dari pikiran guru ke pikiran siswa. Oleh karena itu para guru memfokuskan diri pada upaya penuangan pengetahuan ke dalam pikiran siswa tanpa memperhatikan bahwa ketika siswa memasuki kelas, mereka mempunyai bekal kemampuan, pengetahuan, motivasi yang tidak sama. Metode pembelajaran satu arah dimana siswa hanya ditempatkan sebagai objek dan membatasi kebebasan siswa berperan aktif dalam kegiatan belajar mengajar membuat siswa menjadi malas dan kurang bersemangat dalam mengikuti pelajaran. Penerapan pengajaran ceramah memungkinkan guru lebih mendominasi dalam kegiatan belajar mengajar sehingga siswa menjadi enggan dan jenuh dalam menerima pelajaran sehingga tujuan yang telah ditetapkan tidak tercapai secara optimal. Pada kenyataannya, masih banyak guru yang menggunakan metode konvensional yaitu penyampaian materi pelajaran dengan ceramah.

Umumnya pengajaran berpusat pada guru dan bahan pelajaran, dimana dalam hal ini siswa dipandang sebagai orang yang belum mengetahui apapun tentang materi yang di ajarkan. Oleh karena itu, siswa menjadi pasif dan sering menimbulkan kebosanan. Siswa tidak di tuntut untuk aktif berperan dalam proses belajar mengajar misalnya belajar untuk menemukan sendiri atau memahami konsep-konsep dasar yang diajarkan. Kondisi tersebut di atas juga terjadi di SMA Negeri 5 Binjai, dengan KKM untuk pelajaran geografi 70. Metode yang sering digunakan guru dalam penyampaian materi adalah metode konvensional, walaupun kadang kala ada metode-metode lain seperti Tanya jawab, diskusi, dan kelompok. Namun lebih dominan kepada metode konvensional, sehingga masih di dapati siswa yang memperoleh nilai di bawah KKM. Untuk itu, perlu di usahakan perbaikan pembelajaran siswa dengan lebih memfokuskan pada pembelajaran yang mengaktifkan siswa. Salah satu metode yang digunakan adalah kooperatif tipe . Snowball Throwing .

Snowball Trowing adalah salah satu model pembelajaran kooperatif. Snowball Throwing menurut asal katanya berarti „bola salju bergulir ${ }^{\text {ee }}$ yang dapat diartikan sebagai pembelajaran dengan menggunakan bola pertanyaan dari kertas yang digulung bulat berbentuk seperti bola kemudian dilemparkan secara bergiliran diantara sesama siswa (Isjoni, 2013: 24). Dengan metode ini kegiatan pembelajaran diharapkan lebih efektif sehingga hasil pembelajaran itu sendiri lebih bermakna bagi siswa dan proses pembelajaran berlangsung alamiah dalam bentuk kegiatan siswa bekerja dan mengalami peningkatan motivasi.. Berdasarkan hasil penelitian yang dilakukan oleh Slavin (1995) menunjukkan bahwa teknik- 
teknik pembelajaran kooperatif lebih unggul dalam meningkatkan hasil belajar dibandingkan dengan pengalaman belajar indifidual atau kompetitif. Selain itu beberapa ahli menyatakan bahwa model pembelajaran kooperatif tidak hanya unggul untuk membantu siswa dalam memahami konsep-konsep yang sulit, tetapi juga membantu siswa menumbuhkan kemampuan kerja sama, berfikir kritis dan mengembangkan sikap social siswa.

Untuk mewujudkan hal ini, sangat diperlukan peran guru secara aktif, sebab guru sebagai pengelola proses pembelajaran bertindak selaku fasilitator hendaknya berusaha menciptakan kondisi pembelajaran yang kondusif, mengembangkan bahan pengajaran dan meningkatkan kemampuan siswa untuk menyimak dan menguasai tujuan pendidikan yang harus mereka capai, oleh karena itu guru dituntut mampu mengelola proses pembelajaran yang dapat memberikan rangsangan kepada siswa sebagai subyek utama belajar. Diharapkan dalam proses belajar mengajar dapat terjadi aktivitas dari siswa yaitu siswa mau dan mampu memecahkan masalah, berfikir, menjawab pertanyaan, diskusi, dan memperhatikan pada semua kegiatan pembelajatan di kelas. Selain itu, diharapkan pula siswa mampu berinteraksi secara positif antara siswa yang satu dengan siswa yang lain maupun antara siswa dengan guru apabila ada kesulitan-kesulitan yang dihadapi dalam belajar, sehingga masalah yang dihadapi mudah diselesaikan secara bersama-sama antar mereka. Dalam memilih metode mengajar harus disesuaikan dengan tujuan pengajaran, materi pengajaran dan bentuk pengajaran (kelompok atau individu). Di samping itu, siswa yang sebelumnya kurang aktif menjadi lebih terbuka dan mau bekerjasama dengan teman-temannya ketika berdiskusi. Siswa lebih berani dalam mengungkapkan hasil pemikiran masing-masing dalam mempersentasekan hasil diskusi kelompoknya. Dari uraian di atas, maka Penulis melakukan penelitian dengan judul "Upaya Peningkatan Hasil Belajar Georafi Pada Materi Sebaran Flora Dan Fauna Di Indonesia Dengan Metode Pembelajaran Kooperatif Tipe Snowball Trowing Kelas XI-IPS 2 SMA Negeri 5 Binjai Semester I Tahun Pelajaran 2014/2015.

\section{METODE}

Penelitian ini dilaksanakan di SMA Negeri 5 Binjai . Kelas yang diteliti adalah Kelas XI IPS-2 dengan jumlah 40 siswa. Subjek penelitian ini adalah siswa dan guru Biologi SMA Negeri 5 Binjai. Siswa yang dijadikan subjek penelitian ini adalah siswa Kelas XI-IPS 2.

Data penelitian yang dikumpulkan berupa informasi tentang hasil belajar siswa dalam pelajaran Geografi pada Materi Sebaran flora dan fauna serta kemampuan guru dalam menyusun rencana pembelajaran dan melaksanakan pembelajaran (termasuk penggunaan strategi pembelajaran) di kelas. Alat Pengumpul Data Lembar Observasi, Pedoman 
wawancara, Daftar Nilai Siswa. Teknik analisis data yang digunakan adalah teknik deskriptif kualitatif berdasarkan hasil observasi terhadap motivasi belajar dan hasil belajar.

Proses penelitian tindakan kelas ini direncanakan berlangsung dalam dua siklus. Tiap siklus terdiri atas empat tahap, yaitu perencanaan, tindakan, observasi, dan refleksi.

\section{HASIL DAN PEMBAHASAN}

Berdasarkan hasil diskusi dengan pengawas maka pembelajaran yang dilaksanakan sudah menunjukkan kemajuan. Hal ini ditunjukkan dengan adanya keberhasilan siswa yang dapat menguasai pelajaran Geografi pada materi persebaran flora fauna di indonesia dimana hasil yang diperoleh adalah $87,5 \%$ tuntas dalam pembelajaran lebih dari $75 \%$ yaitu $87,5 \%$ pada siklus II. Disamping itu juga terdapat kemajuan dalam hal prestasi belajar dimana nilai siswa dari pra siklus ke siklus I, dan dari siklus ke Siklus II, nilai evaluasi selalu meningkat. Peningkatan tersebut dapat dilihat pada berikut :

Perkembangan Hasil Evaluasi Belajar Geografi Materi persebaran flora fauna di Indonesia Siswa Kelas XI-IPS 2 SMA Negeri 5 Binjai

\begin{tabular}{|c|l|c|c|c|}
\hline \multirow{2}{*}{ No } & \multicolumn{2}{|c|}{$\begin{array}{c}\text { Kondisi Awal } \\
\text { (Pra Siklus) }\end{array}$} & \multicolumn{2}{|c|}{$\begin{array}{c}\text { Setelah Perbaikan } \\
\text { Pembelajaran }\end{array}$} \\
\cline { 4 - 5 } & & & Siklus I & Siklus II \\
\hline 1 & Nilai terendah & 45 & 40 & 60 \\
\hline 2 & Nilai tertinggi & 75 & 85 & 100 \\
\hline 3 & Nilai Rata-rata & 62,9 & 68,125 & 84,575 \\
\hline
\end{tabular}

Berdasarkan tabel 8 tersebut di atas, maka dapat diketahui bahwa terjadi peningkatan yang signifikan setiap siklus, dimana nilai terendah dapat naik dari kondisi awal $=45$; siklus I $=40$; dan Siklus II: 60 . Nilai tertinggi juga mengalami kenaikan dari pra siklus $=75$, siklus I = 85 dan Siklus II = 100. Rata-rata kelas juga mengalami kenaikan yang signifikan yaitu dari kondisi awal $=62,9$; pada siklus $\mathrm{I}=68,125$; dan Siklus II $=84,575$.

Peningkatan kualitas pembelajaran yang diperoleh siswa berdasarkan dari nilai yang diperoleh setelah diadakannya evaluasi pada setiap siklus mengalami peningkatan yang ditandai dengan meningkatnya nilai setiap siswa dalam akhir pembelajaran pada evaluasi materi di depan kelas.

Adapun rekapitulasi pengelompokan ketuntasan siswa dalam pembelajaran geografi dan persentasenya dapat dilihat pada berikut :

Rekapitulasi Ketuntasan Siswa dalam Pembelajaran Geografi Siswa 
Kelas XI IPS -2 SMA Negeri 5 Binjai

\begin{tabular}{|l|c|c|c|c|c|c|}
\hline \multirow{2}{*}{ Kriteria } & \multicolumn{2}{|c|}{ Pra Siklus } & \multicolumn{2}{c|}{ Siklus I } & \multicolumn{2}{c|}{ Siklus II } \\
\cline { 2 - 7 } & $\mathrm{N}$ & Persen & $\mathrm{N}$ & Persen & $\mathrm{N}$ & Persen \\
\hline \hline $\begin{array}{l}\text { TidakTuntas } \\
\text { Nilai < 65 }\end{array}$ & 19 & $47,5 \%$ & 16 & $40 \%$ & 4 & $10 \%$ \\
\hline $\begin{array}{c}\text { Tuntas } \\
\text { Nilai } \geq 65\end{array}$ & 21 & $52,5 \%$ & 24 & $60 \%$ & 36 & $90 \%$ \\
\hline \hline Jumlah & 40 & $100 \%$ & 40 & $100 \%$ & 40 & $100 \%$ \\
\hline
\end{tabular}

Keterangan :

$\mathrm{N}$ : Jumlah siswa

Berdasarkan tabel di atas maka dapat disajikan diagram batang untuk membandingkan tingkat ketuntasan siswa sebelum perbaikan (pra siklus), siklus I, dan Siklus II dalam pembelajaran Geografi pada materi persebaran flora fauna di Indonesia Kelas XI IPS-2 SMA Negeri 5 Binjai, sebagai berikut :

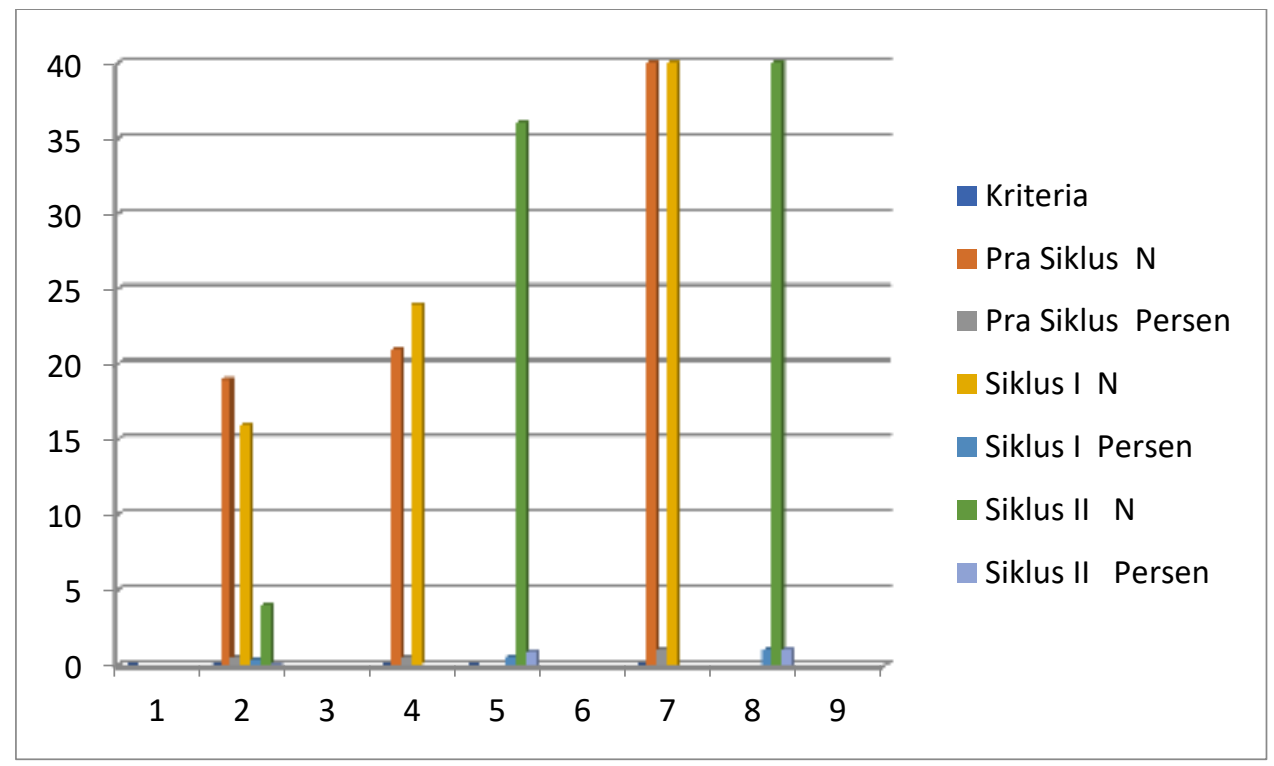

Diagram Batang Perbandingan Ketuntasan Pembelajaran Geografi

Pra Siklus, Siklus I, dan Siklus II

Dari gambar di atas dapat dijelaskan bahwa pada proses pembelajaran Geografi pada Kelas XI-IPS 2 dengan materi persebaran flora fauna di Indonesia, setelah diadakan evaluasi diperoleh hasil yang tidak memuaskan dimana sebanyak 19 siswa atau 47,5\% siswa tidak tuntas sebagaimana Kriteria Ketuntasan Minimal (KKM) yang telah ditetapkan yaitu 65. Sedangkan yang mempunyai nilai 65 ke atas sebanyak 21 siswa atau 52,5\% 
Untuk itu diadakan perbaikan pembelajaran dengan siklus I dengan menggunakan metode belajar kelompok kooperatif snowball trowing. Hasil siklus I adalah sebanyak 24 siswa atau 60\% tuntas, sedangkan 16 siswa atau 40\% siswa tidak tuntas. Hal ini berarti ada peningkatan terhadap ketuntasan belajar siswa. Tetapi peningkatan ini belum seperti yang diharapkan yaitu di atas $75 \%$ dari jumlah siswa. Untuk meningkatkan prestasi belajar siswa Kelas XI IPS-2 maka diadakan lagi perbaikan pembelajaran dengan Siklus II.

Pada siklus II hasil yang dicapai adalah sebanyak 36 dari 40 siswa atau 90\% tuntas dan terdapat 4 siswa yang nilainya di bawah 65 atau 10\% siswa tidak tuntas. Hal ini berarti ada peningkatan terhadap ketuntasan belajar siswa. Peningkatan ini sudah seperti yang diharapkan yaitu di atas $75 \%$ dari jumlah siswa. Kriteria ketuntasan $90 \%$ yang berada di atas 75\% ini menandakan bahwa perbaikan pembelajaran pada Siklus II telah berhasil.

Berdasarkan hasil penelitian sampai pada Siklus I dan Siklus II, maka hipotesis penelitian yang mengatakan bahwa, "Upaya Peningkatan Hasil Belajar Geografi Pada Materi Sebaran Flora Dan Fauna Di Indonesia Dengan Metode Pembelajaran Kooperatif Tipe Snowball Trowing Kelas XI-IPS 2 SMA Negeri 5 Binjai Tahun Pelajaran 2014/2015”. terbukti kebenarannya.

\section{SIMPULAN}

Berdasarkan hasil pengolahan data dari perbaikan pembelajaran yang telah dilaksanakan dapat ditarik kesimpulan :

1. Perbaikan pembelajaran Geografi pada Materi Persebaran Flora Fauna di Indonesia melalui siklus I dan Siklus II dimaksudkan agar siswa lebih aktif dalam pembelajaran dengan model Snowball Trowing. Dengan pembauran ini diharapkan siswa yang kurang terpacu untuk memperoleh prestasi yang baik dan yang berprestasi baik dapat memberikan bimbingan kepada yang nilainya kurang dan sedang.

2. Hasil penelitian: Pra siklus: Penguasaan materi Geografi sebelum diadakan perbaikan pembelajaran (pra siklus) dan siswa yang tuntas dalam pembelajaran adalah 21 dari 40 siswa atau 52,5\% dan yang tidak tuntas adalah 19 atau 47,5\% dari 40 siswa. Pada siklus I siswa yang tuntas dalam pembelajaran adalah 24 dari 40 siswa atau $60 \%$ dan yang tidak tuntas adalah 16 dari 40 siswa atau 40\%; Pada Siklus II, Siswa yang tuntas dalam pembelajaran sebanyak 36 dari 40 siswa atau 90\% dan yang tidak tuntas adalah 4 dari 40 siswa atau $10 \%$.

3. Berdasarkan hasil penelitian Siklus I dan Siklus II, maka hipotesis penelitian yang mengatakan bahwa, “Upaya Peningkatan Hasil Belajar Geografi Pada Materi Sebaran 
Flora Dan Fauna Di Indonesia Dengan Metode Pembelajaran Kooperatif Tipe Snowball Trowing Kelas XI-IPS 2 SMA Negeri 5 Binjai Tahun Pelajaran 2014/2015”, terbukti kebenarannya

4. Penggunaan pendekatan pembelajaran snowball throwing dalam meningkatkan keaktifan belajar siswa ini dirasakan cukup efektif karena mampu menumbuh kembangkan potensi intelektual, sosial, dan emosional yang ada dalam diri siswa. Di sini siswa akan terlatih untuk mengemukakan gagasan dan perasaan secara cerdas dan kreatif, serta mampu menemukan dan menggunakan kemampuan analitis dan imajinatif yang ada dalam dirinya untuk menghadapi berbagai persoalan yang muncul dalam kehidupan sehari-hari.

\section{REFERENSI}

Arikunto, S., (2008), Dasar-dasar Evaluasi Pendidikan, Bumi Aksara, Jakarta.

Djamarah, S , B,. (2006), Strategi Belajar Mengajar, Rineka Cipta, Jakarta.

Hamalik, O,. (2001), Strategi Belajar Mengajar CBSA, Sinar Baru, Ban,dung.

Hutagaol, P,. (1992), Pengaruh Pemberian Tujuan Belajar Dan Ringkasan terhadap Perolehan Belajar Dan Retensi Pada Pengajaran Modul, Tesis, PPS IKIP Malang, Malang.

Ibrahim, M,. Rahmadiarti, F,. Nur, M,. dan Ismono, (2000), Pembelajaran Kooperatif, Universitas Negri Surabaya University Press, Surabaya.

Ikhsan, Fuad, (2005), Dasar-dasar kependidikan, penerbit rineka cipta, Jakarta

Siallagan,A., ( 2010 ) Penerapan Model Pembelajaran Snowball Trowing dalam Meningkatkan Hasil Belajar Siswa,http// portalgandaorg/article php?article, diekses tanggal 3 Desember 2014

Yulianti, (2015), Efektifitas Penggunaan Model Kooperatif Tipe snowball throwing Untuk Meningkatkan Hasil Belajar Siswa pada Materi Sistem PertidaksamaanLinear di kelas XI SMA Negeri 7 Banda Aceh.

Fatimah, Adawiah.R, Dan Ilham.N., (2013) Meningkatkan Aktivitas Dan Hasil Belajar Siswa Melalui Model Pembelajaran Snowball Throwing Pada Materi Sistem Politik Di Indonesia Kelas X C Sma Negeri 3Banjarmasin 